Helen B. Boholano*

Cebu Normal University*

Roberto C. Cajes

Trinidad Municipal College

George Stewart Boholano

Trinidad Municipal College
Original scientific paper

UDC: 371.39

DOI: $10.5937 /$ IstrPed2101098B

\title{
TECHNOLOGY BASED TEACHING AND LEARNING IN JUNIOR HIGH SCHOOL
}

\begin{abstract}
Integrating technology in teaching junior high school motivates, capacitates and prepares the $21^{\text {st }}$ century learners in the Fourth Industrial Revolution. The use of technology to enhance instruction enables the learners to be productive. This study ascertained the effectiveness of using technology in teaching Junior high school in the public schools. The study employed QUAN-QUAL methods for data gathering. The participants of the study were informed on the objectives of this study and their rights in the conduct of the study. To validate the data gathered, focus group discussion was conducted. Results revealed that the use of technology improves performance. Teachers' productivity skills and the ability to use technology were enhanced as they utilized ICT in instruction. Thus, the junior high school learners were technology literate and acquire the $21^{\text {st }}$ century skills.
\end{abstract}

Keywords: technology based-teaching, $21^{\text {st }}$ century skills, technology literate, ICT integration.

\section{INTRODUCTION}

The use of technology in teaching and learning is one of the $21^{\text {st }}$ century skills. Teachers in basic education "must learn to use technology and must allow it to change their present teaching paradigm" (Bitner \& Bitner, 2002). Change is the only constant thing the teaching learning process. Adopting one of the $21^{\text {st }}$ century skills is essential for personal and professional development as well as for the improvement of student performance. According to Koehler and Mishra (2009) teaching with technology has a lot of changes and is complicated especially with the newer technologies present to teachers. In the same study, they added that "the word technology applies equally to analog and digital, as well as new and old, technologies".

Teachers view most traditional pedagogical technologies such as pencil, microscope, chalkboards, transparency and the like are simple and directly referred to technology. Technology is developed by human being such as the above mention equipment. But in the $21^{\text {st }}$ century, technology is not limited to the use of computer in the classroom but also include application of education apps wherein students can learn many things online and offline. "Digital technologies such as computers, laptops, handheld devices, and software applications by contrast, are protean (usable in many different ways; Papert, 1980); unstable (rapidly changing); and opaque (the inner workings are hidden from users; Turkle, 1995)", as mentioned by Koehler and Mishra (2009). 
In the Philippines, the Department of Education conducted several training to capacitate teachers in teaching and learning with the use of technology. Many private institution and non-government agencies work hand-in-hand in order to realize this vision to utilized technology in instruction. In the study of Koehler and Mishra (2009), they mention that because of the busy schedule of the teachers, the skills acquisition on technology is very challenging. Intensive training-workshop provides educators with skills and knowledge on the basic as well as advance use of computer and computer applications (Bitner \& Bitner, 2002) for they need to have a fundamental understanding of how to use computer in teaching and learning.

In some public schools, many teachers tried to integrate technology in teaching and learning. Boholano (2018) stress that the improvement in the educational community requires the teachers and staff to equipped the young people with the use of technology, "which allow them to benefit from the emerging new forms of socialization, globalization and internationalization which can contribute actively to economic development under a system where the main asset is knowledge". ICT therefore provides both learners and teachers with more possibilities, productivity, professional growth and development.

Teachers in basic education particularly in high school should be not only aware to the basic ICT skills but also obtain mastery of the $21^{\text {st }}$ century skills because these made the teaching and learning fun, enjoyable and convenient. Junior high school teachers found out new knowledge through accessing, selecting, organizing, and interpreting information and data with the use of technology. This prompted the researchers to conduct this study in order to verify if all the learned competencies by the teachers were cascading to the classroom.

\section{Objectives of the Study}

This study ascertained the effectiveness of using technology in teaching Junior high school in the public school. Specifically, it sought to:

1. Determine how ICT is taught in school;

2. Identify the conditions and availability of ICT equipment in schools;

3. Find out the ICT based and materials use for teaching; and

4. Determine the prospects and challenges of integrating technology in teaching and learning.

\section{SHORT LITERATURE REVIEW}

Several studies revealed that technology integration is very effective. Askin (2002) mentioned that "technology is a rapidly developing and changing phenomenon, resulting in great challenges and changes for educators and education." This implies that educators and education are changing because of the development of technology. Lee (1997) as cited in Askin (2002) stress that "teachers may not only have the knowledge about the technology but also to have experienced successful models of computer integration in a teaching and learning environment in order to have effective adoption of new technologies in the classrooms". In Abulon (2014), it was stated that "teachers have also identified specific personality traits that have a positive impact on both their classroom management skills as well as to their commitment to students' overall well-being." 
Moreover, the use of technology in the classroom requires learners and teachers to have positive outlook. In the study of Abulon (2014) used of interactive teaching approach and technology is very important in the classroom "as well as highlighting the importance of authentic learning and student-centeredness" because teachers should have pedagogical knowledge and technological content knowledge. This innovativeness in teaching methods should be part of the teachers' expectations and responsibilities in terms of their instructional competence, efficacy and creativity. ICT in education has potential value Alemu (2015), in which all teachers and students should use technology to support and improve their teaching and learning practices. In addition, Blurton (1999) as cited in Boholano (2014) mentioned that the "new digital ICTs are not single technologies but combinations of hardware, software, media, and delivery systems". ICT is used to enhanced teaching and learning that is why it was utilized by different school whether public or private from basic education to higher education. In Holmes Group (1995) as cited in Askin (2002) found out that teachers' preparation in the use of ICT in the learning environments requires support from administration to work together to improve learning and practice. Moreover, (Alemu, 2015) mention that education is impossible without the assistance of ICT in the classroom. Accordingly, ICT is a tool for the enabling the teachers and students towards more productive, effective and efficient learning, for this reason using ICT in education cannot be avoided. This means that everybody must learn to use ICT positively.

In the study of Bitner \& Bitner (2002), it is mentioned that teachers must learn to use positively technology and must allow it to change their present teaching paradigm and practices. Alemu (2015) found out that "the use of ICT in education lends itself to more student-centred learning settings and often this creates some tensions for some instructors and students". The integration of ICT into teaching-learning is becoming more and more important in the $21^{\text {st }}$ century because education is moving rapidly into digital media and information.

Moreover, the "effectiveness of integrating ICT into teaching-learning depends on high levels of interactivity amongst and between students and teachers, and between students and the technologies they use" (Alemu, 2015). In Fu (2013), "Information and Communication Technology (ICT) includes computers, the Internet, and electronic delivery systems such as radios, televisions, and projectors among others, and is widely used in today's education field." Some of this equipment are not available in public school setting because of the limited supplies and infrastructure problems.

These related studies and literature are beneficial basis of this endeavour. In the study of Alemu (2015) teachers feel that there is a need for basic ICT skills retooling in order to enhance their ICT skills necessary in exploring more effective ways of teaching and learning using technology to the $21^{\text {st }}$ century learners.

On the other hand, there are teachers who did not use ICT in teaching which can be explained by a number of reasons. Enochsson and Rizza (2009) revealed that "attitudes towards technology and resistance to change were identified as early explanations (Fabry \& Higgs, 1997). Research has revealed that teachers use ICT to a great extent for personal use (e.g. Merchant \& Heptworth, 2002), although statistics from Sweden show that teachers use computers less for personal use than the average citizen (Knowledge Foundation, 2006; Nordicom, 2008), and student teachers in Sweden as well as USA use ICT less than other students (CMA, 2009; Salaway, Caruso, \&Nelson, 2008)". Thus, personal preference of the 
teachers matters most. Alemu (2015) mentioned that "ICT integration can have a positive impact in teaching and learning process, which takes place in the teaching and learning situation".

Thus, use ICT as a pedagogical way in improving instruction is essential. McMahon (2009) as cited in Fu (2013) showed that studying with ICT integration and the acquisition of critical thinking skills were statistically significant to improve performance. ICT is just a tool in teaching and learning wherein the approach and techniques utilized by the teacher is very important. In Watts-Taffe et al. (2003) as cited in Fu (2013) found that "teachers can act as catalysts change in the integration of technology through positive use of ICT". Thus, teachers' initiative in technology integration is determining factor in a successful lesson delivery.

As cited in Boholano (2017) "digital literacy skills are absolutely necessary to ensure the technology is used to supplement-and not substitute for-high-quality instructional methods" and positive use of technology develops both teachers and students to be globally competitive. The Junior high school teachers using digital technology in the classroom with valuable skills is the most powerful tools in teaching the 21st century learners.

The above mentioned literature and studies are beneficial in the present studies. The use of ICT in teaching and learning can be developed and delivered to enhance teaching and learning as pedagogical skills rather than as a separate unit or using and applying ICT as technical skills.

\section{RESEARCH METHODOLOGY}

The study utilized mixed methods of qualitative and quantitative research for data collection. Researchers made survey questionnaires and interview guides were distributed to the participants of this study. These questionnaires were validated by experts in the field. It was also tried out in other schools to ensure reliability of the questionnaires. All participants were briefed on the purpose of this study and their rights to withdraw anytime at their own convenience. To validate its entry, focus group discussion was conducted after the data collection. The study was conducted in different public high schools in Bohol. The data gathered were tabulated, analysed, presented and interpreted.

\section{Ethical Considerations}

This research is purely academics and there's no financial involvement. The researchers are not going to give anything to the respondents to avoid bias results. The names and personal information of the respondents are not stated in the study. If photos or videos are taken, the researchers make sure to ask permission from the respondents and the assurance of privacy to blur their faces. The data and information that have been collected are confidential. Then they will be eradicated and burned after the researchers make use of them. Recordings were destroyed after interpreting the data gathered.

The researchers prepared and gave an Assent and Consent form as an evident that the respondents voluntarily participated in this study and the permission of their parents is asked. 


\section{RESULTS}

After gathering the data, it was tabulated and interpreted. The table and figure below reveal the findings of the study. The Junior high school teachers integrated technology in teaching in most of their subjects handled.

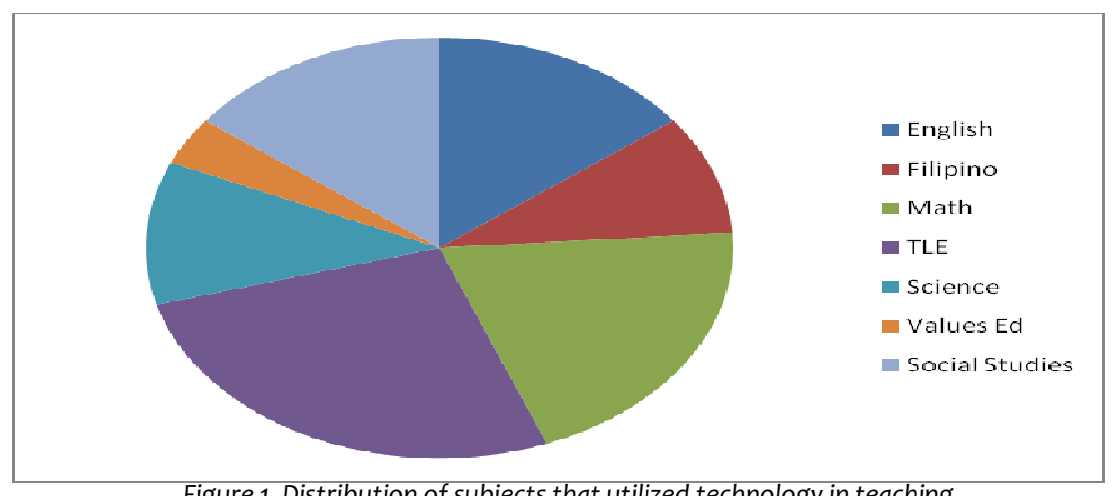

Figure 1. Distribution of subjects that utilized technology in teaching

Figure 1 reveals that teachers in Technology and Livelihood Education are using technology in teaching. Students were given projects and allowed to use technology in creating their tasks. Teachers' utilized print based technology for enhancement of the lesson. In the study of Hooperand Rieber (1995) "teachers could not function without the support of such printbased technologies". Most of the teachers utilized computer in Technology and Livelihood Education topics. Some of the narrative views of the teachers were:

"I like my students when I am using technology in the classroom because they are very attentive" (Teacher A). "In my class, technology is very helpful because my students are very eager to learn. Every time I am giving a test, there scores increases. They enjoy the activity and the interactive discussion" (Teacher B).

This implies that the use of technology improves the performance of the learners. Junior high school academic competence maybe defined as a multidimensional construct consisting of the content knowledge, skills, attitudes and values of students that contribute to success in the classroom (DiPerna \& Elliott, 2002). In the $21^{\text {st }}$ century, the student's academic success in the classroom includes lifelong learning skills which required more than academic skill proficiency but also soft skills such as collaboration, creativity and communication skills.

Table 1. Conditions and availability of ICT equipment in schools

\begin{tabular}{lll}
\hline & Yes & No \\
\hline Desktop computer without internet connection & $41 \%$ & $59 \%$ \\
Desktop computerwith internet connection & $30 \%$ & $70 \%$ \\
Smart TV & $25 \%$ & $75 \%$ \\
LCD/DLP Projector & $45 \%$ & $55 \%$ \\
\hline
\end{tabular}

Table 1 presents the availability of ICT tools and equipment in teaching and learning. The teachers are still very eager to use technology despite the absence of this equipment. They are very creative in such a way that they downloaded offline materials for teaching and 
learning. The students were seen to be computer literate and use computers to produce the majority of their classroom activities (Holland, Holland, \& Davies, (2004).

The public schools do not have smart TV but this is not a hindrance for successful ICT integration. Teachers are creative in doing their task. The Junior high school teachers viewed integrating ICT in teaching and learning is an added learning and opportunities for success classroom experience. In the study of Alemu (2015) the teachers' "priorities are still for more basic computer skills and knowledge despite the fact that they have already received some basic ICT training. The evidence suggests that instructors are still in the early stages of ICT development". In this study, teachers are also very eager to learn current way of integrating ICT in teaching and learning.

Table 2. ICT based activities and materials used in teaching

\begin{tabular}{lll}
\hline & Yes & No \\
\hline Browse/search the internet to gather material to prepare lessons & $89 \%$ & $11 \%$ \\
Browse/search the internet to gather resources to be used during class & $83 \%$ & $17 \%$ \\
discussion & $81 \%$ & $19 \%$ \\
Use application software to prepare presentations for lessons & $80 \%$ & $20 \%$ \\
Create digital learning materials for students & $90 \%$ & $10 \%$ \\
Formulate activities and tasks for students & $50 \%$ & $50 \%$ \\
Post assignment for students on the school website & $53 \%$ & $47 \%$ \\
Use ICT to provide feedback and/or assess students' learning & $56 \%$ & $44 \%$ \\
Communicate parents through online & $70 \%$ & $30 \%$ \\
Evaluate digital learning resources & $40 \%$ & $60 \%$ \\
Download/upload/browse material from the school's website & $85 \%$ & $15 \%$ \\
Download/upload/browse material from a learning platform & $92 \%$ & $8 \%$ \\
Look for online professional development opportunities & & \\
\hline
\end{tabular}

Table 2 shows the eagerness of the junior high school teachers to integrate and use technology in teaching and learning. The school do not have a very good internet connection but the teachers in their own little way do their best in order to utilize ICT in teaching. This implies that they wanted to teach the $21^{\text {st }}$ century skills to the learners. Learning resources can be downloaded at the Department of Education website and other open source websites. In the study of $\mathrm{Ha}$ and Lee (2019), it was indicated that public high schools need to change aspects of their instructional methods utilized in the classroom and technology operating systems for the benefits of the students. In this study, despite of the unavailability of the equipment the teachers do their best to integrate technology in teaching and learning. "Information and Communication Technology (ICT) generally relates to those technologies that are used for accessing, gathering, manipulating and presenting or communicating information" Alemu (2015). ICT equipment and technologies could include hardware; software applications for teachers and students; and internet connectivity. Thus, teachers show a vital specialized role in ensuring that the integration of ICT into teaching and learning is effectively and efficiently implemented. Junior high school teachers must evaluate the appropriateness and effectiveness of available technologies in the classroom for them to decide when and how to use them in the teaching and learning process.

In Fu (2013), "ICT in learning and teaching did not depend exclusively on printed materials" but on various resources such as Internet in which readily available video clips, audio sounds for auditory learners, visual and graphical presentation and so on are commonly available. Many researches had specified that technology assists in converting a teacher-centered environment into a learner-centered setting (Castro Sanchez \& Aleman, 2011 as cited in Fu, 
2013). Thus, the junior high schools teachers are diligent in accessing this materials online and making it available in their respective classrooms.

\section{Opportunities and challenges of integrating ICT in teaching and learning}

The successful ICT integration is coupled with prospects and challenges encountered by the junior high school teachers. Below are thematic analysis based on the teachers accounts.

\section{Theme 1: ICT integration is important}

The following are the accounts of teachers during the implementation:

"I like ICT integration, but our problem is the unavailability of equipment such as LCD projector, SMART TV, whiteboard and internet connection (Teacher C). Moreover, the students also spend their own money in accessing the assignment given by the teachers because the school do not have internet connection (Teacher D).

"I also downloaded materials from he internet and make it available for my students" (Teacher E).

ICT integration is important. Junior high school teachers encountered challenges in integrating technology teaching and learning. These challenges were overcome through the dedication of teachers in their respective work. Askin (2002) emphasis that the use of technology in teaching provided unrestricted access to video, tutorials, simulations, graphical, audio, and textual material useful in the classroom. The challenges and opportunities encountered by the teachers were translated into intrinsic motivation and positive determination.

\section{Theme 2: ICT integration helps students focus on HOTS concepts}

The teachers downloaded videos related to their lessons so that the students can learn easily the lesson. Koc (2005) as quoted in Fu (2013) "mentioned that using ICT enables students to communicate, share, and work collaboratively anywhere and anytime" such as teleconferencing classroom, messenger chat and email messaging. The use of ICT in teaching and learning helps students focus on higher-level concepts rather than less meaningful tasks (Levin \& Wadmany 2006) as cited in Fu (2013). According to the students that ICT is interesting and lessons become more interactive and relevant with the sue of ICT.

\section{Theme 3: Limited Resources}

There are also challenges encountered by teachers in ICT integration, in the study of Frederick, Schweizer and Lowe (2006) as cited in Alemu (2015) revealed that "student mobility, special needs, and anxiety over standardized test results are the main challenges associated with ICT use". One of the participants said:

I like ICT but ICT don't like me. This is because I don't have laptop or tablet but I tried my very best to learn and explore ICT by going to internet café. 
This implies that students are very creative in terms of acquiring skills in ICT. In the study of Whelan (2008) and Alemu (2015), it is mentioned that "these challenges can be solved by providing more authentic group- and problem-based learning activities and adequate learning support". In this study, teachers translated challenges to opportunities because they are motivated to teach children.

\section{DISCUSSIONS}

Many studies revealed that the use of technology improve students' performance. "Smart education is not just about education with smart devices, but it should be an educational paradigm and approach that smart technology can offer but the traditional classroom-based education had hardly afforded according to Ha and Lee (2019)". The purpose of this study is to ascertain the effectiveness of using technology in teaching Junior high school in the public school. The study of Goldberg, Russell and Cook (2003) as cited in Gulek and Demirtas (2005) found that students who use computers as a tool in learning are not only more engaged, use ICT in crafting their projects and motivated in their study, but also produce extraordinary work that is of greater and higher quality, especially at the junior high school level. This present study indicates that participation of student in the classroom with the use of technology had significant positive effects on students' achievement both written and performance.

In the study of Ha and Lee (2019), it is stated that rather than learning from only teacher's input and lectures, "many students are becoming accustomed to exploring new knowledge and expanding their learning and interests through the media". The students possess $21^{\text {st }}$ century skills in the acceleration of technological era thus in-class learning should no longer a teacher-centred (Boholano, 2017) but student centred and technology based. Consequently, in the study of Cagiltay et al. (2001) as mentioned in Askin (2002) found that "teachers were not sufficiently trained to use computers in their classroom but they agreed that technology will significantly influence education and that the ultimate goal of teacher computer literacy training should be to have computer-literate teachers who utilize computer technology successfully in the classroom." This implies that teachers' capacity building is very important for successful technology integration. Alemu (2015) identifies some challenges in integrating ICT in teaching and learning such as ICT "integration is as much at the centre of a conflict between old and new pedagogies/teaching-learning as it is in terms of how educational values practiced by the students that might influenced by institutional imperatives for change and existing social contexts". Thus, positive use of ICT must always be remembered and practiced.

The use of technology provides more creative and sophisticated solutions to different types of learning inquiries (Fu, 2013) such as e-books and the like wherein teachers will be more comfortable through personal computers, laptops, personal digital assistants (PDAs),or iPads. In the classroom, "ICT is the necessity for strong, committed leadership whose knowledge and commitment goes beyond the rhetoric of support" (Alemu, 2015). The teachers' personal commitment to utilize this equipment in the classroom leads the effective ICT integration.

There are several benefits and advantages derived from the integration of ICT tools in increasing quality teaching and learning such as "the ability for student to choose when to learn irrespective of geographical location without stress", ability to collaborate with others and the ability to ascertain and discover new concepts or transformations as stated by Alemu (2015). 


\section{CONCLUSION}

Collectively, technology based teaching and learning capacitate students the $21^{\text {st }}$ century skills. Integrating ICT in education has positively changed and influences the practices and techniques of all forms of active endeavour within educational places. Through the use of technology in teaching, the students became creative and innovative. There is a robust emphasis on incorporating technology into the teaching and learning in the $21^{\text {st }}$ century with a focus on the local and global technologies available in the classroom. With this, classroom became more interactive and engaging.

\section{References:}

Abulon, E. L. (2014). Basic education teacher's concept of effective teaching: inputs to teacher education curriculum in the Philiphines. In INTED2014 proceedings (pp. 850-860). IATED.

Alemu, B. M. (2015). Integrating ICT into Teaching-Learning Practices: Promise, Challenges and Future Directions of Higher Educational Institutes. Universal journal of educational research, 3(3), 170-189.

Askin, A. (2002) Pre-service teachers' use of technology to create instructional materials: a school-college partnership. Journal of Information Technology for Teacher Education, 11:2, 217-232, DOI: 10.1080/14759390200200133

Bitner, N. \& Bitner, J. O. E. (2002). Integrating technology into the classroom: Eight keys to success. Journal of technology and teacher education, 10(1), 95-100.

Boholano, H. B. (2018). IMT Skills of the Pre-Service Teachers in Cebu City. International Journal of Evaluation and Research in Education, 7(3), 212-220.

Boholano H.B. (2017). Smart Social Networking: 21st Century Teaching and Learning Skills. Res Pedagog [Internet]. 7(1):21-9. Available from: http://research.rs/wpcontent/ uploads/2017/06/2217-7337_v07_n01_p021.pdf

Boholano, H. B. (2014). Fractality in the Utilization of Internet in the World. Open Journal of Social Sciences, 2(04), 179.

DiPerna, J. C.\& Elliott, S. N. (2002). Promoting academic enablers to improve student achievement: an introduction to the mini-series.(Mini-Series). School Psychology Review, 31(3), 293-298.

Enochsson, A. \& Rizza, C. (2009), "ICT in Initial Teacher Training: Research Review", OECD Education Working Papers, No. 38, OECD publishing, () OECD. doi:10.1787/220502872611

Ha, C.\& Lee, S. Y. (2019). Elementary teachers' beliefs and perspectives related to smart learning in South Korea. Smart Learning Environments, 6(1), 3.

Holland, B., Holland, L. \& Davies, J. (2004). An investigation into the concept of mind mapping and the use of mind mapping software to support and improve student academic performance. University of Wolverhampton.

Hooper, S.\& Rieber, L. P. (1995). Teaching with technology. Teaching: Theory into practice, 2013, 154-170.

Fu, J. (2013). Complexity of ICT in education: A critical literature review and its implications. International Journal of education and Development using ICT, 9(1), 112125.

Gulek, J. C. \& Demirtas, H. (2005). Learning with technology: The impact of laptop use on student achievement. The journal of technology, learning and assessment, 3(2). 
Koehler, M. \& Mishra, P. (2009). What is technological pedagogical content knowledge (TPACK)?. Contemporary issues in technology and teacher education, 9(1), 60-70.

\section{Biographical notes:}

Prof. Dr. HELEN B. BOHOLANO is a Professor VI of Cebu Normal University. She was sent to Japan to study Certificate Program in Application of Multimedia Technology for E-Education in 2007. She has been sent to several trainings on Integrating ICT into Teaching and Learning (ICT4E) in the Philippines and abroad. She has several researches published in an international referred journal as well as presented in Malaysia, Thailand, Hong Kong, Vietnam, Singapore, Australia and the Philippines. Her research citations and $\mathrm{H}$-index publications make her a productive researcher. She is also recipient of national and international awards like Most Distinguished Educator (awarded in India) and ISSN awards in the field of Research (Tamil Nadu, India).

ATTY. ROBERTO CAJES is lawyer and educator by profession. He had served as a member of the Provincial Board of Bohol from 1992 to 2001. In his service to the people he has attained multiple achievements such as: one of the most Outstanding Neophyte Congressman of the 12th Congress; a Legislator par Excellence of the year 2002; awarded by the Philippines Media Enforcers, Inc. as Congressman of the Year; Public Servant of the Philippines for 2002; and the Development of the Filipino Youth Inc. as an Outstanding Congressman of the year 2002.At present, he is the College President of Trinidad Municipal College, Trinidad Bohol.

Ar. GEORGE STEWART Q. BOHOLANO is an administrator and proprietor of Geen Ed Consultancy, Training \& Review Center. An accredited Continuing Professional Development (CPD) Provider in the Philippines. 